\title{
PENYELESAIAN SISTEM PEMBENTUKAN SEL PADA HYDRA MENGGUNAKAN METODE BEDA HINGGA SKEMA EKSPLISIT
}

\author{
The Solution of System Cell Formation in Hydra using by \\ Finite Difference Method Explicit Scheme \\ Y. Sambono ${ }^{1}$, Z. A. Leleury ${ }^{2 *}$, B. P. Tomasouw ${ }^{3}$, D. L. Rahakbauw ${ }^{4}$ \\ 1,2,3,4 Jurusan Matematika, Fakultas Matematika dan Ilmu Pengetahuan Alam, Universitas pattimura \\ Jln. Ir. M. Putuhena, Kampus Unpatti, Poka-Ambon, 97233, Maluku, Indonesia \\ e-mail:2*zetharthur82@gmail.com; ${ }^{3}$ bptomasouw@gmail.com; ${ }^{4}$ lodewyik@gmail.com. \\ Corresponding author*
}

\begin{abstract}
Abstrak
Model matematika yang mengkaji pola pembentukan sel pada Hydra dinyatakan dalam sebuah system persamaan yang dikenal dengan model Meinhardt. Model ini merupakan model kontinu berbentuk persamaan difusi sehingga untuk menyelesaikannya maka perlu dilakukan diskritisasi. Model beda hingga merupakan salah satu metode numerik yang dapat menggambarkan bentuk diskrit dari suatu bentuk diferensial kontinu. Pada penelitian ini, digunakan metode beda hingga skema eksplisit. Kelebihan dari skema eksplisit adalah mudah diterapkan dalam menyelesaikan persamaan diferensial parsial non linier. Dalam penelitian ini digunakan beda hingga maju untuk turunan $t$ dan beda hingga pusat untuk turunan $x$ pada persamaan activator $a(x, t)$ dan inhibitor $b(x, t)$. Berdasarkan hasil penelitian diperoleh bahwa grafik populasi sel pengaktif memiliki pertumbuhan sel yang cenderung naik per satuan waktu, berbeda dengan grafik populasi sel penghambat yang cenderung menurun pertumbuhan selnya per satuan waktu.
\end{abstract}

Kata Kunci: Metode beda hingga, Persamaan Meinhardt, Skema eksplisit

\begin{abstract}
Mathematical models that describes the pattern of cell formation in Hydra are expressed in a system of equations known as the Meinhardt model. This model is a continuous model in the form of diffusion equations. Thus, one of the studies which can be applied to Meinhardt equation is discretization. The finite difference model is a numerical method that can describe the discrete form of a continuous differential form. The method used in this study is finite different methods implementing explicit scheme. The advantage of the explicit scheme is easier to use for solving non-linear partial differential equations. This method used finite forward difference for derivatives of t and finite centre difference for derivatives of $x$ at theactivator $a(x, t)$ and inhibitor $b(x, t)$. The Steps conducted by analyzing Meinhardt equation andcontinued with discretization such that earn the solution of system cell formation in Hydra. According to the research its found that the activator cell population graphic have cell growth disposed ascend by the unit time, be different with the inhibitor cell population disposed descend of cell growth by the unit time.
\end{abstract}

Keywords: Explicit scheme, Finite difference method, Meinhardt equation 


\section{PENDAHULUAN}

Sel adalah kumpulan materi paling sederhana yang dapat hidup dan merupakan unit penyusun semua makhluk hidup [1]. Sel mampu melakukan semua aktivitas kehidupan [2]. Hydra adalah metazoan atau hewan bersel banyak yang hidup di kolam atau di sungai/empang yang airnya mengalir. Tubuh Hydra berbentuk polip yang soliter dalam arti tidak berkoloni, dapat berpindah tempat tetapi biasanya melekat pada objek, misalnya bebatuan, batang kayu, dan tanaman. Tubuhnya berbentuk silindris yang dapat dijulurkan serta dipendekkan karena memang tubuh Hydra memiliki fibril-fibril khusus pada beberapa sel. Panjang tubuh Hydra mulai dari 2 sampai $20 \mathrm{~mm}$, dengan diameter tubuhnya tidak lebih dari $1 \mathrm{~mm}$ [3] . Proses pembentukan pola dasar suatu organisme terjadi sekali dalam jangka waktu yang relatif singkat. Hydra merupakan suatu organisme yang dapat meregenerasi tubuhnya setiap saat [4]. Dengan demikian, Hydra merupakan model organisme pada sistem biologi yang dapat dikaji terkait dengan sistem pembentukan sel. Hans Meinhardt adalah seorang ahli yang merumuskan pola pembentukan sel Hydra berbentuk suatu model matematika berbentuk sistem persamaan diferensial parsial. Model matematika adalah himpunan dari rumus atau persamaan berdasarkan fenomena nyata dan dibuat dengan harapan dapat merepresentasikan dengan baik fenomena nyata tersebut menurut ilmu yang melatarbelakanginya [5]. Model yang dirumuskan oleh Meinhardt ini berupa model kontinu. Oleh karena itu, untuk menyelesaikan sistem ini maka pendekatan yang dilakukan adalah melalui proses diskritisasi.

Diskritisasi merupakan proses kuantisasi sifat kontinu. Kuantisasi diartikan sebagai proses pengelompokan sifat-sifat kontinu pada selang-selang tertentu (step size). Kegunaan diskritisasi adalah untuk mereduksi dan menyederhanakan data, sehingga didapatkan data diskrit yang lebih mudah dipahami, digunakan, dan dijelaskan. Oleh karena itu, pembelajaran dengan bentuk diskrit dipandang sebagai hasil yang cepat dan akurat dibandingkan hasil dari bentuk kontinu [6]. Diskritisasi dapat dilakukan dengan berbagai metode, salah satunya adalah metode beda hingga. Metode ini telah diaplikasikan pada pemecahan persamaan panas dengan kondisi awal non lokal [7] dan sangat efisien serta memiliki akurasi tinggi pada pemecahan persamaan gelombang akustik dalam media heterogen tiga dimensi [8]. Pada penelitian ini diterapkan metode beda hingga skema eksplisit. Kelebihan dari skema eksplisit adalah lebih mudah digunakan untuk menyelesaikan persamaan diferensial parsial non linier. Beberapa penelitian terbaru telah menerapkan metode beda hingga skema eksplisit untuk memecahkan berbagai persamaan antara lain persamaan gelombang [9], persamaan dinamika gas satu dimensi [10], persamaan Allen-Cahn [11], dan juga model novel termal untuk modul fotovoltaik [12]. Adapun tujuan dari penelitian ini ialah untuk mengkaji dan menyelesaikan sistem pembentukan sel Hydra serta memperoleh bentuk diskrit dari persamaan tersebut dengan menggunakan metode beda hinga skema eksplisit sehingga dapat diketahui kecenderungan pertumbuhan dari populasi sel pengaktif dan sel penghambat.

\section{METODE PENELITIAN}

\subsection{Metode Beda Hingga}

Dalam metode beda hingga skema eksplisit, ruas kanan ditulis pada waktu ke $n$. Dalam skema implisit, ruas kanan ditulis untuk waktu $n+1$. Pada kedua skema dimaksud maka diferensial terhadap waktu dapat ditulis dalam bentuk:

$$
\frac{\partial T}{\partial t} \approx \frac{\left(T i^{n+1}-T i^{n}\right)}{\Delta t}
$$

yang berarti diferensial terpusat terhadap waktu $n+\frac{1}{2}$. Skema Crank-Nicolson menulis ruas kanan pada waktu $n+\frac{1}{2}$ yang merupakan nilai rerata dari skema eksplisit dan implisit. Skema jaringan titik hitungan diberikan oleh Gambar 1, berikut: 


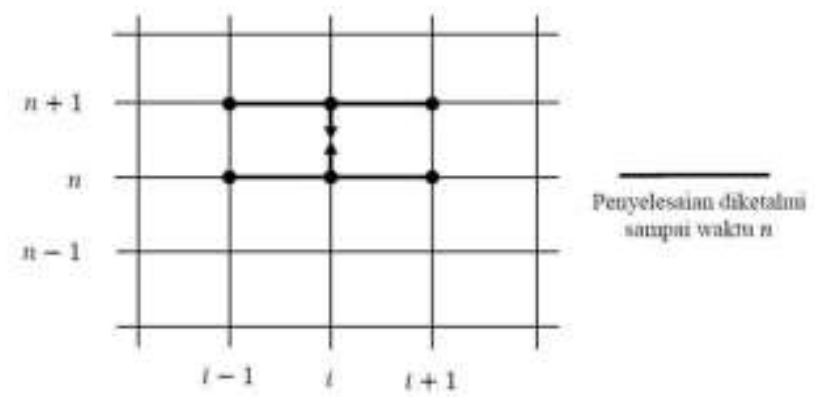

Gambar 1. Skema Crank-Nicolson

$$
\frac{\partial^{2} T}{\partial x^{2}}=\theta\left(\frac{T_{i+1}^{n+1}-2 T_{i}^{n+1}+T_{i-1}^{n+1}}{(\Delta x)^{2}}\right)+(1-\theta)\left(\frac{T_{i+1}^{n}-2 T_{i}^{n}-T_{i-1}^{n}}{(\Delta x)^{2}}\right)
$$

Dengan $0 \leq \theta \leq 1$ adalah faktor pemberat waktu [13]. Sedangkan untuk beda hingga terhadap waktu:

$$
\frac{\partial T}{\partial t}=\frac{T_{i}^{n+1}-T_{i}^{n}}{\Delta t}
$$

Dengan $\theta$ adalah koefisien pembobot dengan nilai [14]:

$\theta=0$, jika skema adalah eksplisit

$\theta=1$, jika skema adalah implisit

$\theta=\frac{1}{2}$, jika skema adalah Crank-Nicolson

Sehingga Persamaan (2) dapat ditulis sebagai:

$$
\frac{\partial^{2} T}{\partial x^{2}}=\frac{1}{2}\left(\frac{T_{i+1}^{n+1}-2 T_{i}^{n+1}+T_{i-1}^{n+1}}{(\Delta x)^{2}}\right)+\frac{1}{2}\left(\frac{T_{i+1}^{n}-2 T_{i}^{n}-T_{i-1}^{n}}{(\Delta x)^{2}}\right)
$$

\subsection{Model Meinhardt (Pembentukan Sel Hydra)}

Pembentukan sel Hydra dipengaruhi oleh zat pengaktif dan zat penghambat yang terjadi melalui proses difusi yaitu gerakan molekul dari suatu daerah dengan konsentrasi tinggi ke daerah lain dengan konsentrasi lebih rendah yang disebabkan oleh energi kinetik molekul-molekul tersebut [15]. Tiap molekul cenderung bergerak lurus sampai terbentur pada molekul lain kemudian terpental dan bergerak ke arah lain. Setelah tersebar secara merata maka molekul tersebut tetap bergerak, tetapi apabila ada molekul yang bergerak dengan cepat dari kiri ke kanan, secepat itu pula ada molekul lain yang bergerak dari kanan ke kiri sehingga keseimbangan dapat dipertahankan. [16] merumuskan sebuah model matematika yang menggambarkan pola pembentukan sel pada Hydra. Persamaan Meinhardt terdiri dari dua persamaan yang berjenis persamaan difusi. Dengan mendefinisikan $a(x, t)$ sebagai activator (pengaktif) dan $b(x, t)$ sebagai inhibitor (penghambat) pembentukan sel. Persamaan Meinhardt ditulis dalam bentuk sebagai berikut:

$$
\begin{aligned}
& \frac{\partial a}{\partial t}=s b a^{2}-r_{a} a+D_{a} \frac{\partial^{2} a}{\partial x^{2}} \\
& \frac{\partial b}{\partial t}=b_{b}-s b a^{2}-r_{b} b+D_{b} \frac{\partial^{2} b}{\partial x^{2}}
\end{aligned}
$$

dimana :

$$
\begin{aligned}
& a=\text { Pengaktif (activator) } \\
& b=\text { Penghambat (inhibitor) } \\
& s=\text { Kepadatan Sel } \\
& D_{a}=\text { Difusi Pengaktif }
\end{aligned}
$$


$D_{b}=$ Difusi Penghambat

$r_{a}=$ Kerusakan Pengaktif

$r_{b}=$ Kerusakan Penghambat

$b_{a}=$ Laju Produksi Pengaktif

$b_{b}=$ Laju Produksi Penghambat

\subsection{Tahapan Penelitian}

Adapun tahapan yang dilakukan dalam penelitian ini adalah sebagai berikut:

- Mendiskritisasi persamaan Meinhardt yang merupakan sebuah model matematika yang menggambarkan pola pembentukan sel pada Hydra dengan menggunakan metode beda hingga skema eksplisit,

- mencari solusi numerik dari model matematika pembentukan sel Hydra tersebut.

- melakukan simulasi dengan bantuan softwere Matlab,

- Analisis hasil simulasi, dan

- membuat kesimpulan hasil simulasi.

\section{HASIL DAN PEMBAHASAN}

\subsection{Model Pengaruh pengaktif dan penghambat}

Parameter yang digunakan dalam model pengaruh pengaktif dan penghambat terhadap pembentukan sel pada Hydra diambil dari jurnal yang dirumuskan oleh Hans [16] dalam karya tulisnya yang berjudul Models of Biological Pattern Formation sebagai berikut:

Pengaktif (activator) $a(x, t)$

$$
\frac{\partial a(x, t)}{\partial t}=s b(x, t) a^{2}(x, t)-r_{a} a(x, t)+D_{a} \frac{\partial^{2} a(x, t)}{\partial x^{2}(x, t)}
$$

Penghambat (inhibitor) $b(x, t)$

$$
\frac{\partial b(x, t)}{\partial t}=b_{b}-s b(x, t) a^{2}(x, t)-r_{b} b(x, t)+D_{b} \frac{\partial^{2} b(x, t)}{\partial x^{2}(x, t)}
$$

Perubahan konsentrasi pengaktif persatuan waktu sebanding dengan kepadatan sel $s$ yang menggambarkan kemampuan sel tersebut untuk melakukan reaksi dan sebanding dengan berkurangnya kerusakan pengaktif melalui pertukaran dengan sel tetangganya akibat difusi. Sedangkan perubahan konsentrasi penghambat persatuan waktu sebanding dengan laju produksi penghambat dan sebanding dengan berkurangnya kerusakan penghambat [16].

Supaya pembentukan pola dapat terjadi maka penghambat harus berdifusi jauh lebih cepat dari pengaktif $\left(D_{b} \geq D_{a}\right)$. Pola akan stabil jika tingkat kerusakan penghambat lebih tinggi dibandingkan dengan pengaktif $\left(r_{b}>r_{a}\right)$, dan jika keadaan sebaliknya terjadi $\left(r_{a}>r_{b}\right)$ maka osilasi akan terjadi. $b_{a}$ menggambarkan laju produksi activator-independen kecil dari pengaktif yang diperlukan untuk memulai produksi activator autocatalytic pada tingkat rendah pada $a$, misalnya selama regenerasi berlangsung. Dalam kebanyakan simulasi, kepadatan sel $s$ diasumsikan merata kecuali beberapa fluktuasi acak kecil yang memicu pembentukan pola dan yang tetap konstan selama simulasi [16].

\subsection{Diskritisasi Persamaan Meninhardt}

\subsubsection{Diskritisasi dengan Metode Beda Hingga Skema Eksplisit pada Activator}

Berikut merupakan proses diskritisasi model pengaktif, persamaan yang digunakan yaitu persamaan:

$$
\frac{\partial a(x, t)}{\partial t}=s b(x, t) a^{2}(x, t)-r_{a} a(x, t)+D_{a} \frac{\partial^{2} a(x, t)}{\partial x^{2}(x, t)}
$$


Berdasarkan pernyataan [13] sebagaimana tercantum dalam kajian pustaka di atas, maka transformasi beda hingga maju untuk turunan $t$ dan beda hingga pusat skema ekspilist untuk turunan $x$ adalah sebagai berikut:

dan

$$
\frac{\partial a}{\partial t}=\frac{a_{i}^{n+1}-a_{i}^{n}}{\Delta t}
$$

$$
\frac{\partial^{2} a}{\partial x^{2}}=\frac{a_{i-1}^{n}-2 a_{i}^{n}+a_{i+1}^{n}}{(\Delta x)^{2}}
$$

Bentuk beda hingga disubtitusikan ke Persamaan (3), sehingga diperoleh bentuk persamaan diskrit sebagai berikut:

$$
\frac{a_{i}^{n+1}-a_{i}^{n}}{\Delta t}=s \cdot b_{i}^{n}\left(a_{i}^{n}\right)^{2}-r_{a} \cdot a_{i}^{n}+D_{a}\left(\frac{a_{i-1}^{n}-2 a_{i}^{n}+a_{i+1}^{n}}{(\Delta x)^{2}}\right)
$$

Persamaan (4) juga dapat ditulis dalam bentuk :

$$
\frac{a_{i}^{n+1}}{\Delta t}=\frac{a_{i}^{n}}{\Delta t}+s \cdot b_{i}^{n}\left(a_{i}^{n}\right)^{2}-r_{a} \cdot a_{i}^{n}+D_{a}\left(\frac{a_{i-1}^{n}-2 a_{i}^{n}+a_{i+1}^{n}}{(\Delta x)^{2}}\right)
$$

Persamaan (5) dikalikan dengan $\Delta t$ pada kedua ruasnya, sehingga diperoleh :

$$
a_{i}^{n+1}=a_{i}^{n}+s \Delta t . b_{i}^{n}\left(a_{i}^{n}\right)^{2}-r_{a} \Delta t \cdot a_{i}^{n}+D_{a} \Delta t\left(\frac{a_{i-1}^{n}-2 a_{i}^{n}+a_{i+1}^{n}}{(\Delta x)^{2}}\right)
$$

Dalam bentuk yang lebih sederhana dan untuk mengelompokkan antara diskritisasi waktu sekarang $(n)$ dan diskritisasi waktu yang akan datang $(n+1)$ dengan memisalkan bahwa:

$$
P=\frac{D_{a} \Delta t}{(\Delta x)^{2}} \quad Q=r_{a} \Delta t \quad R=s \Delta t
$$

maka Persamaan (6) dapat ditulis ulang dalam bentuk

$$
\begin{aligned}
& a_{i}^{n+1}=a_{i}^{n}+R \cdot b_{i}^{n}\left(a_{i}^{n}\right)^{2}-Q \cdot a_{i}^{n}+P\left(a_{i-1}^{n}-2 a_{i}^{n}+a_{i+1}^{n}\right) \\
& a_{i}^{n+1}=P . a_{i-1}^{n}+(1-Q-2 P) \cdot a_{i}^{n}+P \cdot a_{i+1}^{n}+R \cdot b_{i}^{n}\left(a_{i}^{n}\right)^{2}
\end{aligned}
$$

Selanjutnya asumsikan bahwa $M=1-Q-2 P$ dan $c_{i}^{n}=b_{i}^{n}\left(a_{i}^{n}\right)^{2}$ sehingga dengan mensubtitusikan $M=1-Q-2 P$ dan $c_{i}^{n}=b_{i}^{n}\left(a_{i}^{n}\right)^{2}$ pada Persamaan (7) di atas, maka diperoleh:

$$
a_{i}^{n+1}=P \cdot a_{i-1}^{n}+M \cdot a_{i}^{n}+P \cdot a_{i+1}^{n}+R . c_{i}^{n}
$$

\subsubsection{Diskritisasi dengan Metode Beda Hingga Skema Eksplisit pada Inhibitor}

Persamaan penghambat dalam pembentukan sel pada Hydra sebagaimana persamaan:

$$
\frac{\partial b(x, t)}{\partial t}=b_{b}-s b(x, t) a^{2}(x, t)-r_{b} b(x, t)+D_{b} \frac{\partial^{2} b(x, t)}{\partial x^{2}(x, t)}
$$

Transformasi beda hingga maju untuk turunan $t$ dan beda hingga pusat untuk turunan $x$ adalah sebagai berikut:

dan

$$
\frac{\partial b}{\partial t}=\frac{b_{i}^{n+1}-b_{i}^{n}}{\Delta t}
$$

$$
\frac{\partial^{2} b}{\partial x^{2}}=\frac{b_{i-1}^{n}-2 b_{i}^{n}+b_{i+1}^{n}}{(\Delta x)^{2}}
$$

Bentuk beda hingga disubtitusikan ke Persamaan (9), sehingga diperoleh bentuk persamaan diskrit sebagai berikut:

$$
\frac{b_{i}^{n+1}-b_{i}^{n}}{\Delta t}=b_{b}-s \cdot b_{i}^{n}\left(a_{i}^{n}\right)^{2}-r_{b} \cdot b_{i}^{n}+D_{b}\left(\frac{b_{i-1}^{n}-2 b_{i}^{n}+b_{i+1}^{n}}{(\Delta x)^{2}}\right)
$$

Persamaan (10) dapat disederhanakan menjadi : 


$$
\frac{b_{i}^{n+1}}{\Delta t}=\frac{b_{i}^{n}}{\Delta t}+b_{b}-s \cdot b_{i}^{n}\left(a_{i}^{n}\right)^{2}-r_{b} \cdot b_{i}^{n}+D_{b}\left(\frac{b_{i-1}^{n}-2 b_{i}^{n}+b_{i+1}^{n}}{(\Delta x)^{2}}\right)
$$

Persamaan (11) dikalikan dengan $\Delta t$ pada kedua ruasnya, sehingga diperoleh:

$$
b_{i}^{n+1}=b_{i}^{n}+b_{b} \Delta t-s \Delta t \cdot b_{i}^{n}\left(a_{i}^{n}\right)^{2}-r_{b} \Delta t \cdot b_{i}^{n}+D_{b} \Delta t\left(\frac{b_{i-1}^{n}-2 b_{i}^{n}+b_{i+1}^{n}}{(\Delta x)^{2}}\right)
$$

Dalam bentuk yang lebih sederhana dan untuk mengelompokkan antara diskritisasi waktu sekarang $(n)$ dan diskritisasi waktu yang akan datang $(n+1)$ dengan memisalkan bahwa:

$$
T=\frac{D_{b} \Delta t}{(\Delta x)^{2}} \quad U=r_{b} \Delta t \quad V=s \Delta t \quad W=b_{b} \Delta t
$$

maka persamaan (12) dapat ditulis ulang dalam bentuk:

$$
\begin{aligned}
& b_{i}^{n+1}=b_{i}^{n}+W-V \cdot b_{i}^{n}\left(a_{i}^{n}\right)^{2}-U \cdot b_{i}^{n}+T\left(b_{i-1}^{n}-2 b_{i}^{n}+b_{i+1}^{n}\right) \\
& b_{i}^{n+1}=W+T \cdot b_{i-1}^{n}+(1-U-2 T) b_{i}^{n}+T \cdot b_{i+1}^{n}-V \cdot b_{i}^{n}\left(a_{i}^{n}\right)^{2}
\end{aligned}
$$

Selanjutnya asumsikan bahwa $N=1-U-2 T$ dan $c_{i}^{n}=b_{i}^{n}\left(a_{i}^{n}\right)^{2}$ sehingga dengan mensubtitusikan $N=1-U-2 T$ dan $c_{i}^{n}=b_{i}^{n}\left(a_{i}^{n}\right)^{2}$ pada Persamaan (13) di atas, maka diperoleh:

$b_{i}^{n+1}=W+T \cdot b_{i-1}^{n}+N \cdot b_{i}^{n}+T \cdot b_{i+1}^{n}-V \cdot c_{i}^{n}$

Dari proses diskritisasi di atas, maka diperoleh sistem persamaan Meinhardt diskrit sebagai berikut :

$a_{i}^{n+1}=P \cdot a_{i-1}^{n}+M \cdot a_{i}^{n}+P \cdot a_{i+1}^{n}+R \cdot c_{i}^{n}$

$b_{i}^{n+1}=W+T \cdot b_{i-1}^{n}+N \cdot b_{i}^{n}+T \cdot b_{i+1}^{n}-V . c_{i}^{n}$

Dari sistem persamaan diskrit di atas, untuk $i=1,2,3, \cdots, j$ maka diperoleh persamaan aljabar terkait dengan untuk Persamaan activator (6) yang dapat ditulis dalam bentuk persamaan matriks:

$$
\left[\begin{array}{c}
a_{1} \\
a_{2} \\
a_{3} \\
\vdots \\
a_{j-1} \\
a_{j}
\end{array}\right]^{n+1}=\left[\begin{array}{cccccc}
M & P & 0 & 0 & 0 & 0 \\
P & M & P & 0 & 0 & 0 \\
0 & P & M & P & 0 & 0 \\
0 & 0 & \ddots & \ddots & 0 & 0 \\
0 & 0 & 0 & P & M & P \\
0 & 0 & 0 & 0 & P & M
\end{array}\right]\left[\begin{array}{c}
a_{1} \\
a_{2} \\
a_{3} \\
\vdots \\
a_{j-1} \\
a_{j}
\end{array}\right]^{n}+R\left[\begin{array}{c}
c_{1} \\
c_{2} \\
c_{3} \\
\vdots \\
c_{j-1} \\
c_{j}
\end{array}\right]^{n}
$$

Selanjutnya dari persamaan aljabar terkait dengan persamaan inhibitor (12) untuk $i=1,2,3, \cdots, j$ maka diperoleh sistem linier yang dapat ditulis dalam bentuk persamaan matriks:

$$
\left[\begin{array}{c}
b_{1} \\
b_{2} \\
b_{3} \\
\vdots \\
b_{j-1} \\
b_{j}
\end{array}\right]^{n+1}=\left[\begin{array}{c}
W \\
W \\
W \\
\vdots \\
W \\
W
\end{array}\right]+\left[\begin{array}{cccccc}
N & T & 0 & 0 & 0 & 0 \\
T & N & T & 0 & 0 & 0 \\
0 & T & N & T & 0 & 0 \\
0 & 0 & \ddots & \ddots & 0 & 0 \\
0 & 0 & 0 & T & N & T \\
0 & 0 & 0 & 0 & T & N
\end{array}\right]\left[\begin{array}{c}
b_{1} \\
b_{2} \\
b_{3} \\
\vdots \\
b_{j-1} \\
b_{j}
\end{array}\right]^{n}-V\left[\begin{array}{c}
c_{1} \\
c_{2} \\
c_{3} \\
\vdots \\
c_{j-1} \\
c_{j}
\end{array}\right]^{n}
$$

\section{3. Simulasi Numerik}

Berikut disajikan hasil simulasi numerik berupa solusi persamaan Meninhardt terkait dengan pertumbuhan sel pada hydra. Diasumsikan bahwa panjang tubuh hydra adalah $18 \mathrm{~mm}$. Akan ditentukan pertumbuhan sel activator dan sel inhibitor pada setiap jarak $2 \mathrm{~mm}$ di setiap tubuh hydra untuk tiap satuan waktu. Selanjutnya ditetapkan kondisi batas yakni: $\boldsymbol{a}(x, 0)=20 \mathrm{sel}$ dan $\boldsymbol{b}(x, 0)=80 \mathrm{sel}$. 
Tabel 1. Data Estimasi Parameter

\begin{tabular}{cclc}
\hline NO & Parameter & & \multicolumn{1}{c}{ Deskripsi } \\
\hline 1 & $s$ & Kepadatan sel & Nilai \\
\hline 2 & $D_{a}$ & Difusi Pengaktif & 0,0001 \\
\hline 3 & $D_{b}$ & Difusi Penghambat & 0,025 \\
\hline 4 & $r_{a}$ & Kerusakan Pengaktif & 0,4 \\
\hline 5 & $r_{b}$ & Kerusakan Penghambat & 0,01 \\
\hline 6 & $b_{a}$ & Laju Produksi Pengaktif & 0,0 \\
\hline 7 & $b_{b}$ & Laju produksi Penghambat & 0,01 \\
\hline
\end{tabular}

Sumber: [16]

Dengan mensubtitusikan nilai parameter di atas maka diperoleh nilai:

$$
\begin{array}{ll}
P=\frac{D_{a} \Delta t}{(\Delta x)^{2}}=\frac{0.025(1)}{(1)^{2}}=0.025 & Q=r_{a} \Delta t=0.010(1)=0.010 \\
R=s \Delta t=0.0001(1)=0.0001 & T=\frac{D_{b} \Delta t}{(\Delta x)^{2}}=\frac{0.400(1)}{(1)^{2}}=0.400 \\
U=r_{b} \Delta t=0(1)=0 & V=s \Delta t=0.0001(1)=0.0001 \mathrm{~W}=b_{b} \Delta t
\end{array}
$$

Tabel 2. Data hasil simulasi numerik pengaruh pengaktif pada sel Hydra

\begin{tabular}{ccccccccccc}
\hline$n$ & $a_{1}$ & $a_{2}$ & $a_{3}$ & $a_{4}$ & $a_{5}$ & $a_{6}$ & $a_{7}$ & $a_{8}$ & $a_{9}$ & $a_{10}$ \\
\hline 0 & 20 & 20 & 20 & 20 & 20 & 20 & 20 & 20 & 20 & 20 \\
\hline 1 & 22.500 & 23.000 & 23.000 & 23.000 & 23.000 & 23.000 & 23.000 & 23.000 & 22.500 & 22.500 \\
\hline 2 & 23.993 & 25.957 & 25.957 & 25.957 & 25.957 & 25.957 & 25.957 & 25.957 & 25.957 & 24.925 \\
\hline 3 & 25.471 & 29.747 & 28.910 & 28.910 & 28.910 & 28.910 & 28.910 & 28.910 & 28.872 & 27.278 \\
\hline 4 & 26.955 & 33.419 & 34.100 & 31.821 & 31.821 & 31.821 & 31.821 & 31.820 & 31.744 & 29.563 \\
\hline 5 & 28.441 & 37.039 & 39.143 & 38.161 & 34.703 & 34.703 & 34.702 & 34.699 & 34.574 & 31.783 \\
\hline 6 & 29.929 & 40.604 & 44.133 & 44.319 & 42.057 & 37.556 & 37.555 & 37.549 & 37.362 & 33.940 \\
\hline 7 & 31.417 & 44.117 & 49.067 & 50.415 & 49.195 & 45.604 & 40.380 & 40.369 & 40.107 & 36.038 \\
\hline 8 & 32.904 & 47.580 & 53.945 & 56.448 & 56.259 & 53.418 & 48.305 & 43.159 & 42.811 & 38.078 \\
\hline 9 & 34.387 & 50.995 & 58.767 & 62.418 & 63.245 & 61.139 & 56.020 & 49.707 & 45.473 & 40.064 \\
\hline 10 & 35.868 & 54.362 & 63.535 & 68.324 & 70.154 & 68.763 & 63.629 & 56.121 & 49.310 & 41.997 \\
\hline
\end{tabular}

Berdasarkan tabel simulasi numerik maka diperoleh grafik populasi sel pengaktif pada saat $t=0$ sampai $t=10$ adalah sebagai berikut: 


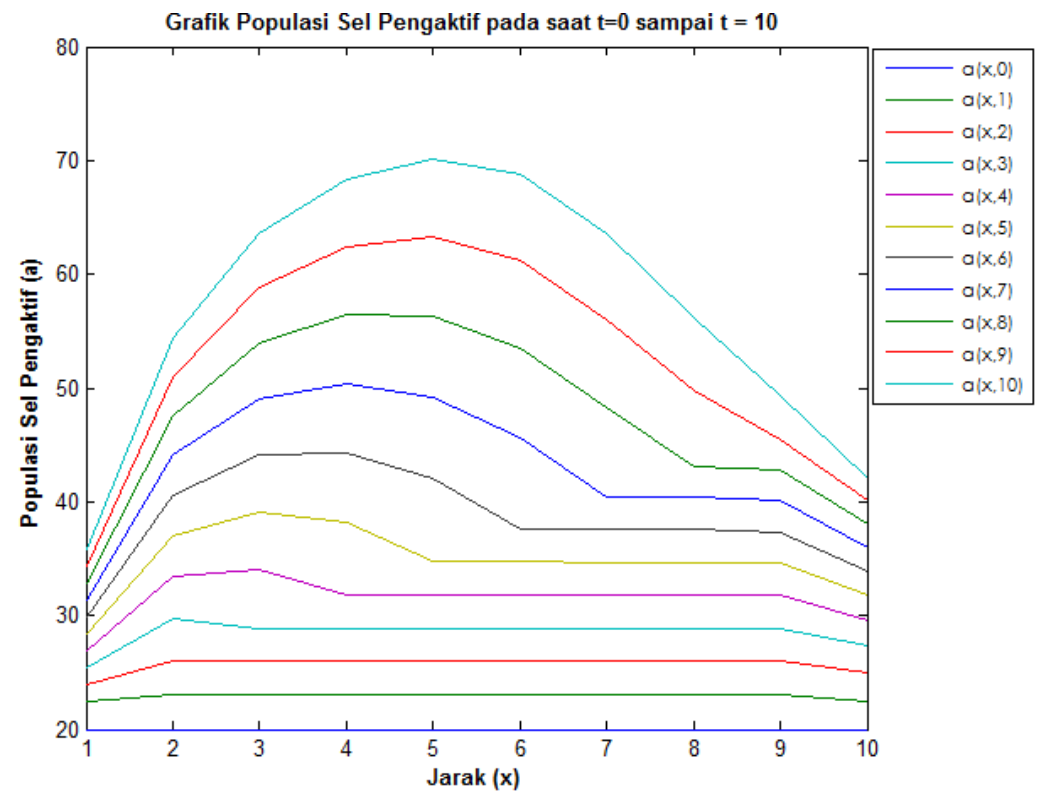

Gambar 2. Grafik Populasi Sel Pengaktif Pada Saat $t=0$ sampai dengan $t=10$

Grafik populasi sel pengaktif yang diperoleh dari hasil simulasi numerik pertumbuhan selnya selalu naik pada saat $t=0$ sampai $t=10$ dan pada saat $t=0$ sampai $t=5$ memiliki pertumbuhan sel yang tidak terlalu signifikan atau cenderung memiliki nilai yang sedikit berbeda. Sedangkan pada saat $t=6$ sampai $t=10$ memiliki pertumbuhan sel yang cukup signifikan atau cenderung memiliki nilai yang jauh berbeda, sehingga dapat dilihat bahwa grafik pertumbuhan sel pada bagian tengah nilainya cukup signifikan. Namun, dibagian ujungnya cenderung tidak terlalu signifikan.

Tabel 3. Data hasil simulasi numerik pengaruh penghambat sel hydra

\begin{tabular}{ccccccccccc}
\hline$n$ & $b_{1}$ & $b_{2}$ & $b_{3}$ & $b_{4}$ & $b_{5}$ & $b_{6}$ & $b_{7}$ & $b_{8}$ & $b_{9}$ & $b_{10}$ \\
\hline 0 & 80 & 80 & 80 & 80 & 80 & 80 & 80 & 80 & 80 & 80 \\
\hline 1 & 44.810 & 76.810 & 76.810 & 76.810 & 76.810 & 76.810 & 76.810 & 76.810 & 76.810 & 44.810 \\
\hline 2 & 37.427 & 60.820 & 73.620 & 73.620 & 73.620 & 73.620 & 73.620 & 73.620 & 60.820 & 36.496 \\
\hline 3 & 29.555 & 52.495 & 65.310 & 70.430 & 70.430 & 70.430 & 70.430 & 65.310 & 53.020 & 28.437 \\
\hline 4 & 24.650 & 44.357 & 56.783 & 65.192 & 67.240 & 67.240 & 65.192 & 59.252 & 44.913 & 23.705 \\
\hline 5 & 20.414 & 37.357 & 49.727 & 56.056 & 63.230 & 63.230 & 60.445 & 52.702 & 38.975 & 19.516 \\
\hline 6 & 16.767 & 31.440 & 41.862 & 49.803 & 52.756 & 58.926 & 55.272 & 47.118 & 33.492 & 16.330 \\
\hline 7 & 13.671 & 25.651 & 35.421 & 41.216 & 46.438 & 46.695 & 50.282 & 41.739 & 28.877 & 13.467 \\
\hline 8 & 10.736 & 20.679 & 28.383 & 34.396 & 36.847 & 39.726 & 37.241 & 36.822 & 24.668 & 11.054 \\
\hline 9 & 8.160 & 15.695 & 22.258 & 26.380 & 29.413 & 29.279 & 29.878 & 25.279 & 20.894 & 8.888 \\
\hline 10 & 5.651 & 11.218 & 15.833 & 19.353 & 20.541 & 21.217 & 19.610 & 18.516 & 13.535 & 6.945 \\
\hline
\end{tabular}

Berdasarkan tabel simulasi numerik maka diperoleh grafik populasi sel penghambat pada saat $t=0$ sampai $t=10$ adalah sebagai berikut 


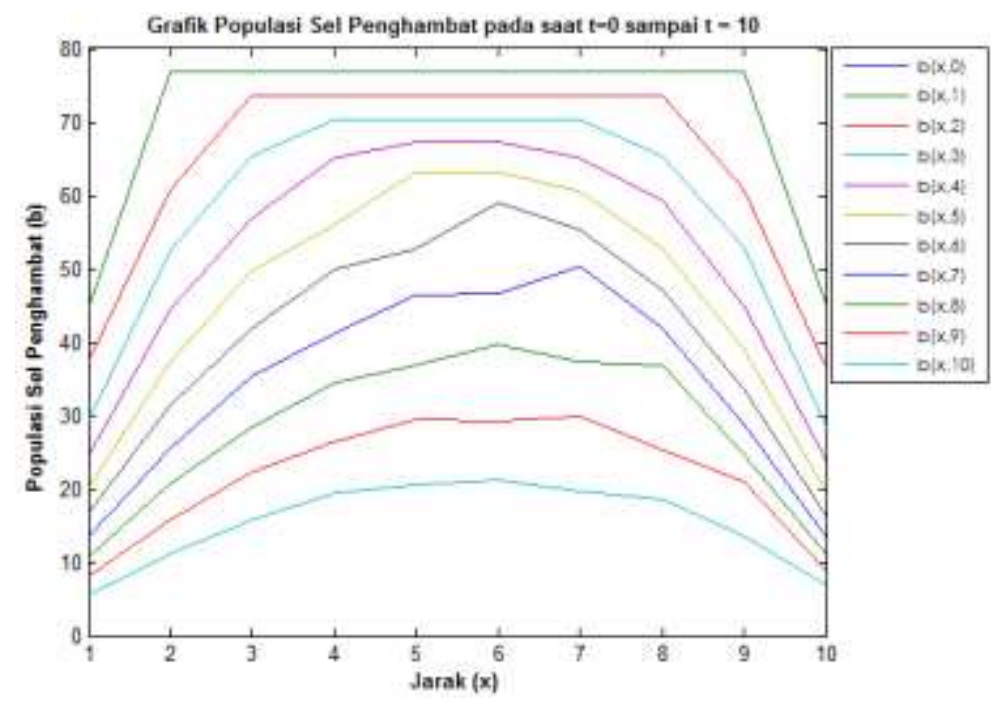

Gambar 3. Grafik Populasi Sel Penghambat Pada Saat $t=0$ sampai dengan $t=10$

Berbeda dengan grafik populasi sel pengaktif. Grafik populasi sel penghambat memiliki pertumbuhan sel yang cenderung menurun. Dapat dilihat pada grafik pada saat $t=0$ sampai $t=5$ memiliki pertumbuhan sel yang tidak terlalu signifikan atau cenderung memiliki nilai yang sedikit berbeda. Sedangkan pada saat $t=6$ sampai $t=10$ memiliki pertumbuhan sel yang cukup signifikan atau cenderung memiliki nilai yang jauh berbeda, sehingga dapat dilihat bahwa grafik pertumbuhan sel pada bagian tengah ke bawah nilainya cukup signifikan. Namun, dibagian ujung atas cenderung tidak terlalu signifikan.

\section{KESIMPULAN}

Berdasarkan hasil pembahasan maka dapat disimpulkan bahwa:

a. Bentuk diskrit dari persamaan Meinhardt dengan menggunakan metode beda hingga skema eksplisit adalah sebagai berikut:

Activator (pengaktif)

$$
a_{i}^{n+1}=a_{i}^{n}+s \Delta t \cdot b_{i}^{n}\left(a_{i}^{n}\right)^{2}-r_{a} \Delta t \cdot a_{i}^{n}+D_{a} \Delta t\left(\frac{a_{i-1}^{n}-2 a_{i}^{n}+a_{i+1}^{n}}{(\Delta x)^{2}}\right)
$$

Inhibitor (penghambat)

$$
b_{i}^{n+1}=b_{i}^{n}+b_{b} \Delta t-s \Delta t \cdot b_{i}^{n}\left(a_{i}^{n}\right)^{2}-r_{b} \Delta t \cdot b_{i}^{n}+D_{b} \Delta t\left(\frac{b_{i-1}^{n}-2 b_{i}^{n}+b_{i+1}^{n}}{(\Delta x)^{2}}\right)
$$

b. Populasi sel pengaktif memiliki pertumbuhan sel yang cenderung naik per satuan waktu, sebaliknya populasi sel penghambat cenderung menurun pertumbuhan selnya per satuan waktu.

\section{DAFTAR PUSTAKA}

[1] N. A. Camphbell and J. B. Reece, Biologi Edisi ke 8 Jilid 1, Jakarta: Erlangga, 2008.

[2] E. Sloane, Anatomi dan Fisiologi Untuk Pemula, Jakarta: EGC, 2003.

[3] Y. Kastawi, Zoology Avetebrata, Malang: UM Press, 2005.

[4] A. Gierer, Biological Features and Physical Concepts of Pattern Formation Exemplified by Hydra. Current Topics in Developmental Biology, Published by Elsevier Inc, 1977.

[5] G. Ledder, Differential Equations: A Modeling Approach, New York: McGraw-Hill, 2005.

[6] H. Liu, F. Hussain, C. L. Tan and M. Dash, "Discretization: An Enabling Technique," Data mining and knowledge discovery, vol. 6, no. 4, 2002.

[7] J. M. Vaquero, S. Sajavicius, "The two-level finite difference scehmes for the heat equation with nonlocal initial condition," Applied Mathematics and Computation, vol. 3421, 2019. 
[8] K. Li, W. Liao, "An efficient and high accuracy finite difference scheme for the acoustic wave equation in 3D heterogeneous media," Journal of Computational Science, vol. 40, 2020.

[9] Y. Liu, "Maximizing the CFL number of stable time space domain explicit finite difference modeling," Journal of Computational Physics, vol. 4161, 2020.

[10] A. Zlotnik, "On L2-dissipativity of linearized explicit finite difference schemes with a regularization on a nonuniform spatial mesh for the 1D gas dynamics equations," Applied Mathematics Letters, vol. 92, 2019.

[11] D. Jeong, J. Kim, “An explicit hybrid finite difference scheme for the Allen-Cahn equation,” Journal of Computational and Applied Mathematics, vol. 3401, 2018.

[12] S. P. Aly, N. Barth, B. W. Figgis, and S. Ahzi, "A fully transient novel thermal model for in-field photovoltaic modules using developed explicit and implicit finite difference schemes," Journal of Computational Science, vol. 27, 2018.

[13] D. Luknanto, Model Matematika., Yogyakarta:: Bahan Kuliah tidak dipublikasikan Jurusan Teknik Sipil FT UGM, 2003.

[14] L. Lapidus and G. F. Pinder, Numerical Solution of Partial Differential Equations in Science and Engineering, New York: A Wiley-Interscience Publication., 1981.

[15] C. A. Villee, General Zoologi Sixth Edition, Jakarta: Erlangga, 1984.

[16] H. Meinhardt, Models of Biological Pattern Formation, 2012. 